\title{
Kadare's Work, an Emancipating Factor in the Albanian Literature
}

\author{
Ermelinda Kashah
}

\author{
University "Eqrem Cabej", The faculty of education and social science
} Departament of leterature, Gjirokastër, Albania

\section{Doi:10.5901/jesr.2013.v3n7p585}

\begin{abstract}
In the Albanian literature, Kadare with his genius encompassed the Albanian thinking and culture. Based on real events to which he gave universal proportions, he has added new characters in the family of great archetypes of world literature, that of Judas Iscariot, Agamemnon, Marcus Brutus, Joseph K, etc,. In the case of Kadare the Albanian word found a great master or a virtuous wizard of its artistic elaboration, as a foreign critic has said about him. Seen in its entirety, his work shows us an impressive array of characters, like a universe which shocks us infinitely with the grotesque and the human tragedy, epic rumbles and fine lyricism. His work is a challenge to isolation, which is a standard of traditional proportions. His work served a model where, except other things at that time, was also a moral act. Kadare's work is great character-wise but also because of its values, is a wok which has become an inseparable part of the entire Albanian nation and has even become part of the cultural fund of mankind.
\end{abstract}

Keywords: Kadare, History, character.

Time does not survive without history. Ismail Kadare is one of the most distinguished writers of the Albanian Literature. Being a poet with a conspicuous talent, and an artist with an innovatory spirit, Kadare has played a significant role in the process of the development of deep regeneration that our literature had ever known. The strengthening of realism and active emotional attitude towards life, the enrichment of our literature with ideas and other means of artistic expression, the depth of thought, of militant breath and civic pathos are all closely tied with the contribution of Kadare, who brought in our literary development a new experience. The literary creativity of Kadare, born on the ground of reality, of great concerns and problems of our time, in the resistance of the Albanian people, has increased the social role of Albanian literature in the struggle of the time. With the significance and depth of ideas it carries and with its artistic level, it has raised in a new higher level the values of artistic word. Ismail Kadare joined the literary life in the years 1950 at a time he was still a student in high school and he began to write in the literary press of the time. In his initial volumes: "The Boyish Inspirations" (1954) and "The Dreams" (1957), which are a result of juvenescent inspirations, a mirror of a poetic world which sought to utter its new and fresh word in Albanian poetry, it seemed that a genuine poet was born, an artist who during his whole life would be accompanied by the spirit of exploration. It is the time when Kadare will began to cultivate the long prose, where his talent will show up with the same force that it showed up in the genre of poetry. It is worth to remind her that "The Great Winter" was published in the year 1973, "The Emblem of the Past" (1977), "The Three-Arched Bridge" (1978)" and "The Cold Blood" (1980). Journalism and Essays are another genre where the talent of Kadare appeared. A part of his journals he included them in the summaries "The Southern Town" (1976) and "The Emblem of the Past", whereas his notes from his journeys abroad he collected them in the book "Distant Lines" (1971). His work:

"The Autobiography of People in Verses" (1980), a more complete variant of the first publication of the year 1971, is the synthesis of his continuous research to penetrate into some essential sides of the historical tradition. Even though peripheral in his creativity, but its part, are the writings for children among which are the poems: "Argyro, the Princess" (1958), "The stonemasons" (1967), "In the museum of weapons" (1978) and the theatrical piece "The fortress and the poison" (1977).

In its wholeness the work is wide and multilateral. In his work are reflected the most subtle problems of the life of the Albanian society, which the creativity of Ismail Kadare has followed in every step during the last thirty years. The work not only enriched the fond of ideas and made history with the ideas and the issue of our literature, but it also brought the diversity of ideas and artistic tools where every endeavor to characterize even the creativity of Kadare in general brought the contribution in the development of the Albanian literature. Albanian men like Kadare were not fighters with swords, but they were fighters with their pen. In addition to that, in determinative moments for the history of Albania he had not played primary roles as a politician, although he had valuated the men of the sword and diplomacy such as Scanderbeg, Abdyl Frashëri, Bajram Curri etc. He had a way of development but also oscillations between a liberal democracy and 
socialism, in the most climacteric moments of Albania.

It is understandable that in this short writing we can not claim a full view and objective exhaustive judgment on the creativity of one of the greatest writers. The aim is to remember and shed light in this great personality. The work of Kadare even in the periods of social crises of reappraisal of man, philosophy etc., in periods of contradictions and human suffers, makes the reader to frequently go back to it. In his creativity take place conspicuous figures which unfold a giant in Albanian history and literature. This man with a great heart who put the talent, human mind and experience close to human sorrow, sought the men and the ways of their survival. It is the man who made his work immortal, because it is written with pain, with love for the people, by one of the most talented people that has emerged in Albania and the whole humanity. His works rank in such a way that they determine the logical and chronological continuity. Some of his works had thematic closeness. The isolation and emphasis of the articles is achieved in two directions: from his direct experiences, from the direct efforts facing the reality and inspiration as a result of active contemplations. This is the window through which the men enter into the world of characters and from where the concern penetrates into the world of the author. In this way, the author through a character, who enters from inside to a time of certain relationships, from all the experiences, the author feels the need to invent and express more thoroughly as inclination and features of cleverness, the narration which has at its disposal an origin of stereotypes of expression, to hyperbolize and fix the superlative, thus bringing another work in our prose to open the world in the width of the streams of its life.

Considered in its wholeness, the work of Kadare appears as a universe which overwhelms you with the endless gallery of characters, with human tragedy, with refined lyricism and epic thunders, and apocalypses of Tyrants and rebirth of peoples. As a literary personality, Kadare faced two trials:

The first was intra-literary and had to do with him, with the exigency and creative spirit. It seems that his works passed the trial of the time distance, which is being witnessed by the warm literary inclination in literary circles. It seems that his works passed the time distance and this appeared in the role of this creativity as an emancipating factor and influent in literary circles. Besides the influence this writer has, rightfully our scholars express their opinions that this prose initiated the doors of Albanian genuine story telling prose, despite the fact that this should not be limited only as a value, within the inauguration of an envied literary genre, far from possible naiveties of an author who had to walk through a tradition almost inexistent in this genre. The cultivation of the genuine prose, for the specter of reflections and interrelations among the characters he creates, for the compositional and expressive structures, a tradition is more than necessary. Owing to his talent and wide culture, Kadare compensated this making another challenge, while he was trying to bring also a modern breath and vision in our prose. It was exactly this inclination which made this creativity to have its followers and admirers in ranks of the future writers, among whom the author will declare openly that he had one of sources of his literary building up, the Albanian nation. The writer was led by some theoretical and literary principles, which not only he had absorbed for himself in advance, but he had also formulated them openly through various writings especially at: "Chronicle in Stone". Without doubt the author was well informed for this problem, treated especially in our century. He insists in the thought that our criticism is a part of our literary science, which on the contrary, is a kind of literary work.

The writer can not escape from the oscillation between that what he claims and that he accomplishes in reality, which proves the superiority of the opinion that criticism is a part of literary science. Another exigent vision, (significant), Kadare unfolds also for the analysis of literary works within the specific laws. Aware in the sky of the Albanian culture, as it has been accepted, he appeared and remained as an extraordinary personality, an elegant arbiter of Albanian letters, a lion of literature and diplomacy. Let us not forget that to this writer the Albanian word found a grand master or a virtuous magician of its artistic treatment, as an English writer is expressed. This culture and this Albanian intellectual thought, the whole culture and Albanian intellectual thought collected in him the dimensions of such a phenomenon which come indeed rarely, but are remembered for a long time. This emancipation i.e. the contemporary, civilizing and progressive inclination, is a feature which not only is manifested and poured in every tissue of his literary work, but also has been also transformed into a emancipating and influential factor in the literary process of the time. This can be observed in some planes:

First of all, his prose carries a multitude of bridges of communication with great literatures, embodying naturally enough massages and segments.

Secondly, the work of Kadare has manifested always an active position toward the standards observed in our literature. The synthesis as an artistic principle which multiplies the artistic information and the interrelationships of the work with the reader, make these features be features of great work and have the fate of communication through generations and through time.

Thirdly, Kadare, in the traces of the great writers of Albanian letters, since his first works and in continuance, he is 
dedicated to the awareness of the cult of Albanian literature and language considering it as an importance with inexhaustible capacities. The language atlas of Kadare is rich with outstanding figures because the work of Kadare overwhelms you with the endless gallery of characters, with the thrown trajectories of epochs, with grotesque and human tragedy of those times.

The same notes cover the poem "Notes for My Generation". In this creation he has found expressions, as exultation for the rhythms with which life in Albania changes, plus the thought for the continuance of traditions of the past generations in the work of the new generations. The author unfolds in his works in a more or less crystallized shape, some of the features of the talent of I. Kadare as a prose writer. The innovatory spirit and artistic thought rises above the simple facts and penetrates into their generalized historic and philosophic meaning, the lyrical way of narration which intertwines some planes and uses widely the mixture of subjects, as a nucleus which reinforces the idea of resistance, of force and historic dynamism, the belief in his future and in the victory of the ideals of progress. If we consider the poem: "Why are these mountains thinking" (1964), this poem is in some sense a synthesis of all the history and motives, in the nucleus of which is formed the idea of resistance, historic dynamism of the Albanian people, belief in the future and the ideals of the national progress. The force of the thought is seen as an essential factor of Albanians, their progressive spirit, dreams for a new epoch, freedom and society, which were embodied in the great social movements of our people. This new force would realize many dreams as ideas of historical turn which denoted life and the necessity of the result of the development of society. If the poetry is the lymph which flows in all the work of Kadare, prose is the most important chapter of his creativity. There are some advantages in this genre compare to other genres for the representation of life and where the writer has found potentials to develop in the historical and philosophical plane. But having in the foundation the meditations and problems of the time, or the fate of the fatherland as a force for his poems which stands in the depth of generalization, living actively the events and experiencing deeply the historical moments that the country passes, I. Kadare in his creativity was gradually reaching in and artistic discovery with significance for the fates of creativity and our literature as a whole. If we consider the novel: "The Guests are frozen", seems that it offers scope for interpretations in different planes, in the flow of time. The horizontal level is related with factuality of the events, with biography as sketches of the characters, with the flow of the real time. In this work there are many records held in 13 February 1979, which is entitled "On the article published in the newspaper "Drita", "On the Epos of the Brave Men" of the writer I. Kadare. Precisely at this time for the first time some of the most distinguished Albanian intellectuals, including I. Kadare were invited to participate in cultural, historical and intercultural polemics that were held at that time. The works showed that the generations were moving where the political scientist Ukshin Hoti has named it the "moment 0". Kadare brings an essential change which he has included in one of his own poetic volumes. Through this character he becomes the premature spokesman. The author in three works of the prose: "The Southern Town" ( 1967), "Chronicle in Stone" and "Issues of Foolishness" ( 2005), treats the subject of his birthplace and evokes the time of his childhood in Gjirokastra.

The author pronounces: "I would have felt myself very difficult as a universal writer, if I had not been firstly a national writer". In the research "Linguistic presentation", Bashkim Kuçuku writes about a wide range of time and for a wide range of understanding in his work, for breaking of the time and the ways of use of metaphors.

If I would say that my first prose has been the novel "Chronicle in Stone", this means that this is so much true as it is untrue. Indeed, because I have written parts of this novel before other novels, but it is untrue because they have been just pieces, i.e. saplings. The sapling of the novel has been the "Southern Town" but it has also had a first sapling, the story "The Big Aircraft". With the vertical of the time are intermingled the present time, the past and the future. Thus, Kadare is a point of reference in this aspect in Albanian literature and in contemporary literature.

\section{References}

I. Kadare, "The guests are frozen", Tirana 1986, p.405.

"On the article published in the newspaper "Drita", "On the Epos of Brave Men" of the author Ismail Kadare in 4 and 11 May of this month". CAA, Fond 14/AP, List 1, File 40, Year 1979, p. 18-24. A part of this writings, including those with the author I. Kadare, are selected and published in the book "About the Events in Kosovo".

U. Hoti, "Political philosophy of the Albanian cause", Tirana 1995, p. 74-71. More generally : Sh. Sinani, "Exorcism of Hatred", in "Pledge of Miscomprehension", Tirana 1997, p. 47-51.

Shaip Beqiri, "The Challenge of the Genius", Buzuku", Prishtina, 1991. p.82.

Bashkim Kuçuku, "Kadare in the languages of the world", "Onufri", Tirana, 2000. p.13

Five questions to Ismail Kadare about the novels, "Nëntori", Tirana, 1972, nr.1, p. 51-53.

"Jeta e ere", Prishtina, 1972, nr. 1 p.190-192. 